\title{
THE RESPONSE OF SOUTHEAST ASIAN AND INDONESIAN ISLAMISTS TO THE FUTUH OF THE TALIBAN: A REFLECTION
}

\author{
Herdi Sahrasad, ${ }^{1}$ Imron Byhaqi, ${ }^{2}$ Al Chaidar, ${ }^{3}$ Mohamad \\ Asrori Mulky, ${ }^{4}$ Mai Dar ${ }^{5}$ \\ ${ }^{1}$ Universitas Paramadina, Jakarta \\ ${ }^{2}$ Independent Researcher at Freedom Foundation \\ ${ }^{3}$ University Indonesia and Universias Malikussaleh Aceh \\ ${ }^{4}$ Pragram Doktoral UIN Syarif Hidayatullah Jakarta \\ ${ }^{5}$ Philipps University Marburg, Jerman \\ email: herdi.nurwanto@paramadina.ac.id
}

\begin{abstract}
This article explains the purpose of establishing the Taliban. It is to restore peace, enforce sharia law, and maintain the Islamic character of Afghanistan. However, in responding to the futuh of the Taliban in Afghanistan, the Indonesian and Southeast Islamists show some differences. For instance, Indonesian Islamists and some radical Islamists in Southeast Asia, such as sympathizers supporting ISIS (Islamic State of Iraq and Syria), actually show the opposite attitude. IS, better known as ISIS (Islamic State of Iraq and Syria), considers the Taliban a sworn enemy and branded them as infidels even though they have the same belief. The Taliban reject terrorism, even fighting ISIS terrorism and the like. In general, however, the Islamists in Indonesia show no euphoric response to the fall of Kabul instead of a plain hope that the Taliban government can rebuild a sovereign, inclusive, dignified, just, and prosperous Afghanistan. الملخص :تهدف هذه الدراسة لبيان قيام طالبان على أنه يعيد آمنا وسلاما وقيام

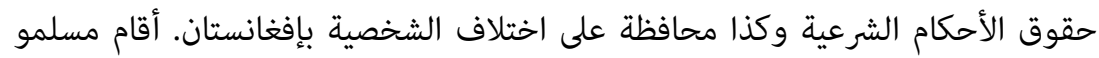

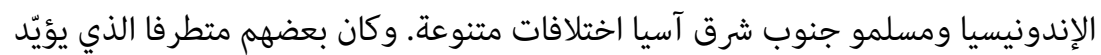

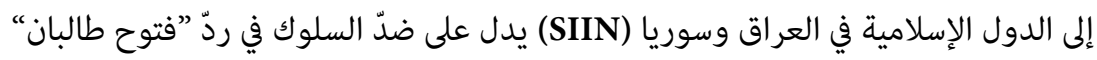
بإفغانستان. اشتهرت الدول الإسلامية في العراق وسوريا (SIIN) بلقب الدول في الدول الإسلامية
\end{abstract}


في العراق والشام (SISI) التى يحتسب طالبان كعدوّهم وينظرهم بالكفار مطلقا ولوكان

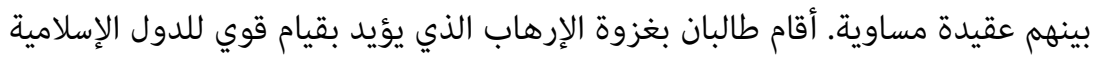

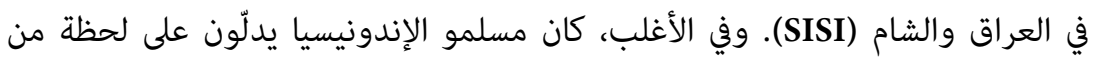

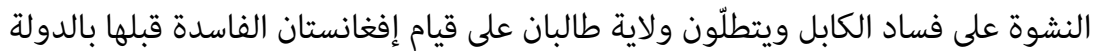
المساحمة والعدالة والموسرة.

Abstrak: Artikel ini menjelaskan tujuan didirikannya Taliban yaitu untuk memulihkan perdamaian, menegakkan hokum syariah, dan mempertahankan karakter Islam Afganistan .Namun dalam merespon futuh Taliban di Afghanistan, kaum Islamis Indonesia dan Asia Tenggara menunjukkan perbedaanperbedaan, Kaum Islamis Indonesia dan sebagian Islamis di Asia Tenggara yang radikal, seperti para simpatisan pendukung NIIS (Negara Islam Irak dan Suriah) justru menunjukkan sikap yang sebaliknya. NIIS atau lebih dikenal dengan sebutan ISIS (Islamic State of Iraq and Syria) menganggap Taliban sebagai musuh bebuyutan dan mencapnya sebagai kafir meskipun berakidah sama. Taliban menolak terorisme, bahkan memerangi terorisme ISIS dan sejenisnya. Secara umum, kaum Islamis di Indonesia menunjukkan respon nir-euforia atas peristiwa jatuhnya Kabul dan berharap pemerintahan Taliban mampu membangun kembali Afghanistan yang berdaulat, inklusif, bermartabat, adil dan sejahtara).

Keywords: Taliban, futuh Afghan, revolution, Islamic nomocracy.

\section{INTRODUCTION}

In Southeast Asia, the victory of the Taliban in Afghanistan is limitedly celebrated by the cells and networks of Jemaah Islamiyah (JI) in this region. There is no tendency of euphoria also occurs when at the end of 2013, ISIS claimed victory and formed its state. At that time, radical movements in Southeast Asia meant that ISIS' victory was a form of struggle and victory for themselves, not for Islamists in general. In Indonesia, only the hardline groups Jamaah Ansharut Daulah (JAD) and the East Indonesia Mujahidin (Mujahidin Indonesia Timur) welcomed and supported the presence of ISIS in the Middle 
East. In contrast, in the Philippines, the Abu Sayyaf group responded happily to ISIS' victory and stated support for it.

In this context, the Taliban's victory in Afghanistan on 15-17 August 2021 is again being greeted to some extent by Islamists in Indonesia with more or less the same celebration. But the Taliban reject terrorism, even fighting ISIS terrorism and the like. The Taliban's return to power in Afghanistan has boosted the morale of militant Islamist groups in Southeast Asia to a certain degree. This paper is an initial investigation of the Taliban victory in August 2021 and the response of the Islamists of Southeast Asia and Indonesia to the Futuh (victory, revolution) of the Taliban.

In this regard, it should be noted that the movement of terrorist groups in Indonesia is more or less influenced by developments at the global and regional levels. More than 2,300 US military members were killed and more than 20,000 injured. Likewise, more than 450 British military personnel and hundreds of others from some countries were injured. But it is Afghans themselves who suffer the most. According to research, more than 60,000 local security forces were killed.

The war has also killed and injured nearly 111,000 civilians since the United Nations systematically recorded civilian casualties in 2009. According to one study, the US war in Afghanistan cost US taxpayers US\$2 trillion. In 2018 and 2019, US-Taliban delegations held secret meetings in Qatar. In February 2020, the US and the Taliban signed a "deal to restore peace" in Afghanistan that had taken years. $^{2}$

After Taliban Takeover, Can Afghanistan's Economy Survive? https://www. usip.org/publications/2021/09/after-taliban-takeover-can-afghanistans-economysurvive. See, https://www.bbc.com/indonesia/dunia-58394441. www.bbc.com

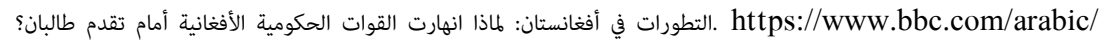

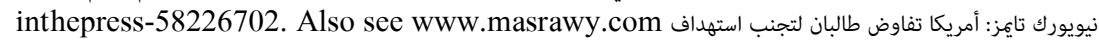
سفارتها لدى أفغانستان

2 Taliban Menang, https://www.tribunnews.com/nasional/2021/08/23/talibanmenang-di-afghanistan-ji-dan-jad-di-indonesia-diperkirakan-bersuka-cita Fakta Taliban, , https://www.republika.co.id/berita/qxwuqw320/12-fakta-tentang-talibanyang-kembali-kuasai-afghanistan-part 1. About Taliban, https://nu.or.id/opini/ mengenal-taliban-ideologi-politik-dan-watak-keberislamannya-izRJa .See, Kharis Hadirin , Taliban Menang di Afghanistan dan Pengaruhnyaterhadap JAD, https:// ruangobrol.id/2021/08/14/fenomena/perdamaian/taliban-menang-di-afghanistan-danpengaruhnya-terhadap-jad/ 
According to the deal, the United States and its NATO allies agreed to withdraw all troops on the condition that the Taliban no longer allow al-Qaeda or other extremist groups to operate in the areas they control. As a result of last year's talks, the Taliban and the Afghan government released prisoners from each other. Nearly 5,000 members of the Taliban militia were released in the months since the deal was made. The US also promised to lift sanctions on the Taliban and coordinate with the United Nations to lift other sanctions against them.

The BBC Arabic newspaper describes a map of the forces held by the Afghan government and the Taliban. The BBC tells the story of two troops supported by NATO forces from all weapons and war equipment in its report. However, the other (Taliban) only has strong motivation from each personnel.

\section{LITERATURE REVIEW}

The Taliban - the Pashtun language, which means student, pupil, student, or student - appeared in the 1980s in the Taliban guerrilla front. They joined the Mujahideen party, Harakat-iEnqelab-Islami (Islamic Revolutionary Movement), against the occupying forces of the Soviet Union (1979-1989). 1992 was involved in a civil war (Antonio Giustozzi, 2019, Giustozzi 2011. Giustozzi, 2007. Davis, 1998. Barfield, 2010). ${ }^{3}$

Using the name Taliban (plural of Talib), they want to distance themselves from Mujahideen politics and hint that they are a movement to purge society and not a party seeking only power. Thus, the purpose of establishing the Taliban is to restore peace, enforce sharia law, and maintain the Islamic character of Afghanistan (Andrew R Smith, 2011. Giustozzi, 2018). The emergence of the Taliban movement cannot be separated from the role of Madrasah educational institutions in Afghanistan, especially in the area of

Antonio Giustozzi, The Islamic State in Khorasan: Afghanistan, Pakistan and the New Central Asian Jihad (HURST publisher 2018). Antonio Giustozzi, The Taliban at War 2001 - 2018 (Oxford: University Press, 2019). Anthony Davis. "How the Taliban Became a Military Force." In Fundamentalism Reborn?, edited by William Maley (New York: NYU Press, 1998). On Afghan society, culture, and politics see: Barfield, Thomas. Afghanistan: A Cultural and Political History (Princeton, NJ: Princeton University Press, 2010). 
Kandahar Province to the southern border of Afghanistan-Pakistan, where many Islamic madrasas have a Wahhabi ideology. ${ }^{4}$

The role of Madrasas in Afghanistan is to become an Islamic educational institution, but instead to carry out social functions that can unite social groups from various ethnicities and tribes. Even the role of Madrasas in Afghanistan was able to articulate Islamic values in the struggle against the influence of the Soviet Union's communist ideology in Afghanistan and the resistance against the Mujahideen government supported by the United States (Salim Basyarahil, 1986. Musthafa Abd. Rahman, 2002. David B. Edwards, 2002). ${ }^{5}$

In the eyes of the Afghan people, Madrasas have a particular position in society. Even in the past, the cultural revolution as a process of modernizing Afghanistan built by Mohammad Zahir Syah did not succeed in marginalizing the role of Madrasahs, instead of tending to get resistance from the Afghan people.

Therefore, until the mid-19th century, Afghanistan did not have a modern school system. Likewise, amid today's modernization, Madr a sahs remain a popular and favorite educational choice for Afghans who congregate as the Taliban.

The war between the Taliban and Ashraf Ghani's Mujahideen government forces is a battle of two social forces in the Afghan land. It is the story of two armies, one of which is poorly equipped but highly motivated. The other is well equipped from a formal point of view but dependent on the US and NATO support, and its leadership is poor and corrupt.

Nasi $r$ Abas, a former high-ranking Jemaah Islamiyah (JI) lead e r, appreciated the quick steps taken by the National Police Head q uarters, which recently arrested more than 50 suspected terrorists affiliated with JI and Jamaah Ansharut Daulah (JAD). JI and JAD welcomed enthusiastically, even euphoric, for the Taliban's victory in Afghanistan. Nasir also reminded the government to be

4 Antonio Giustozzi, Koran, Kalashnikov and Laptop: The Neo-Taliban Insurgency in Afghanistan 2002-2007. New York: Columbia University Press, 2007. See, Andrew R. Smith, Belling the cat: The neo-Taliban insurgency in Afghanistan, Master thesis, University of New Hampshire, Durham, 2011.

5 Salim Basyarahil, Perang Afghanistan (Jakarta: Gema Insani Press, 1986). See, Musthafa Abd. Rahman, Afghanistan di Tengah Arus Perubahan: Laporan dari Lapangan (Jakarta: Kompas, 2002). David B. Edwards, Before Taliban: Genealogies of the Afghan Jihad (California: University of California Press, 2002). 
wary of those celebrating the victory of the Taliban. Moreover, those who call the victory of the Taliban the victory of Islam. "Law enforcement, on standby, must still be consistent, and if necessary, it should be improved," said Nasir. ${ }^{6}$

The Taliban's success in Kabul 15-17 August 2021 is celebrated by Islamists and extremists in Southeast Asia countries, who are also expected to have been revived in their struggle to replace a secular government with an Islamic state. The three countries with genuine grievances in Indonesia, Malaysia, and the southern Philippines will be most affected by a Taliban victory. The victory of the Taliban was greeted with hope and anxiety by the West because it was feared that it would trigger a clash of Islamic and Western civilizations in the Central Asian region and at the global level. But this should not be necessary because the Taliban government wants to cooperate peacefully with the West and all countries in the world and asks for Western economic assistance to strengthen its existence and struggle to form a peaceful Islamic government, uphold human rights and protect women and children. ${ }^{7}$

Noor Huda Ismail of the S. Rajaratnam Institute of International Studies (RSIS) in Singapore said that this Taliban victory would inspire them, strengthen their morale, and boost their morale to continue fighting for their political goals as an Islamic state. Noor Huda added that Islamists would try to learn how to win people's hearts and support from the Taliban. Nasir Abas, the former leader of al-Qaeda's Southeast Asia branch, said jihadist groups were overjoyed that the Taliban had retaken Afghanistan. "Some have expressed their hope and desire to go to Afghanistan. Surely they will go if there is an opportunity for them to undergo military training there," he said. But there is no such euphoria celebrating the futuh Taliban in Indonesia and other countries in Southeastern Asia. ${ }^{8}$

${ }^{6}$ Interview with Nasir Abbas and Noorhuda Ismail and an Afghanistan diplomat in Jakarta in early September 2021.

7 Al Chaidar, Respon Kaum Islamis Indonesia Terhadap Futuh Taliban - https:// modusaceh.co/news/respon-kaum-islamis-indonesia-terhadap-fut uh-taliban/index. html.

8 Yaliban Menang, https://www.tribunnews.com/nasional/2021/08/23/talibanmenang-di-afghanist an-ji-dan-jad-di-indonesia-diperkirakan-bersuka-cita Fakta Taliban, https://www.republika.co.id/berita/qxwuqw320/12-fakta-tentangtaliban-yang-kembali-kuasai-afghanistan-part1. About Taliban, see https://nu.or. id/opini/mengenal-taliban-ideologi-politik-dan-watak-keberislamannya-izRJa. Also 
A senior Indonesian security source said that seven Indonesians who joined ISIS in Afghanistan were among the 5,000 prisoners released by the Taliban from a former US airbase last week. He also said the police's Detachment 88 counter-terrorism force (Densus 88) monitored the situation and watched if they tried to return to Indonesia.

\section{THE AFGHAN LEADERSHIP}

The US negotiates directly with the Taliban, without the presence of the Afghan government. "It's time, after all these years, to bring our citizens home," US President Donald Trump said at the time. During the talks, the Americans hoped to get assurances from the Taliban that they would not attack the US embassy in Kabul. ${ }^{9}$

The New York Times in August 2021, citing 3 US officials, revealed that US negotiators were trying to get assurances from the Taliban that they would not attack the US embassy in Kabul if the movement seized power and wanted foreign help. ${ }^{10}$

The defeat of Ashraf Ghani's US-backed government was primarily the result of mismanagement and corruption. In Afghanistan, this deep-rooted corruption has left the Afghan Armed Forces short of unit commanders who have integrity and are based on meritocracy. Most of them are only concerned with their interests. They are involved in various smuggling practices, ranging from weapons to opium. Their structural position in the past as warlords made them often pretend to be "powerful" and more concerned with the defense of their respective groups - causing the erosion of the spirit of national unity to defend Afghanistan as their country.

The structural failure and mismanagement of the Afghan military would not have occurred if the Afghan government had a clear vision to eradicate various corrupt practices. Law enforcement and transparency should be increasingly a concern. At the same time, the Afghan government needs to open up to its citizens to participate in

see, Kharis Hadirin, Taliban Menang di Afghanistan dan Pengaruhnya terhadap JAD, https://ruangobrol.id/2021/08/14/fenomena/perdamaian/taliban-menang-diafghanistan-dan-pengaruhnya-terhadap-jad/

\footnotetext{
9 Www.bbc.com التطورات في أفغانستان: لماذا انهارت القوات الحكومية الأفغانية أمام تقدم طالبان؟ https://www.bbc.com/arabic/inthepress-58226702

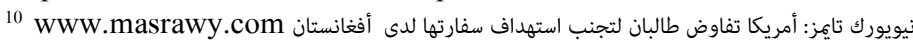
https://www.masrawy.com/news/news_publicaffairs/details/
} 
monitoring government processes, including military management. In addition, from the outset, the Afghan government did not commit to building a competent and professional military.

Al Jazeera, 20/8/2021, made a more detailed report on the causes of Afghanistan's fall into the hands of the Taliban. In addition to corrupt practices by the government elite, there have also been divisions and frictions in government circles. In addition, poor logistical support and over-reliance on special forces have made Afghanistan weaker and more accessible for the Taliban to control. No one foresaw the rapid disintegration of the Afghan National Security and Defense Forces. The critical dysfunction of the Afghan forces that the government has ignored and even exacerbated itself has emerged over the past few years.

No one expected the rapid disintegration of the Afghan National Defense and Security Forces in Kabul. Still, signs of the Taliban's military rule, and the critical dysfunction of Afghan forces that the government has ignored and even exacerbated itself, have emerged over the past few years. All the problems that allowed the Taliban to defeat the Afghan army so quickly in 2021 had become apparent since 2015 , when the movement briefly captured the northern city of Kunduz, exploiting the fragile morale of Afghan forces, fleeing the fighting, attrition, corruption, and ethnic divisions. The ranks, poor logistical support, and over-reliance on special forces. ${ }^{11}$

The Taliban get money from some sources. Over the past two decades, some Western funds have inadvertently gone into the pockets of the Taliban. First, the Taliban uses development and infrastructure projects primarily funded by Western countries, including roads, schools, and clinics. Second, the Taliban is suspected of getting tens of millions of dollars every year from taxes on truck drivers supplying the needs of international troops stationed in various parts of Afghanistan. The Taliban are also suspected of making large sums of money from the opium business and services provided by the Afghan government. The director of an Afghan electricity company told the $\mathrm{BBC}$ in 2018 that the Taliban earns more than $\$ 2$ million a year from

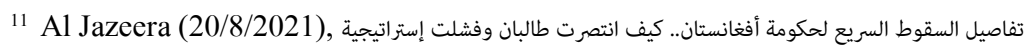
واشنطن؟, https://www.aljazeera.net/midan/reality/politics/ 
charging customers for electricity in various places. Then there is the income generated from the conflict. ${ }^{12}$

Whenever the Taliban captured a military post or city center, they took all the money, guns, cars, and armored vehicles. Taliban also get financial resources from minerals. Afghanistan is rich in minerals and precious stones. Most of the wealth in the earth's bowels has not been mined due to the prolonged conflict. According to Afghan government officials, the mining industry in Afghanistan is estimated to be worth $\$ 1$ billion per year.

The Taliban wielded significant influence, and even as America tried to form a new government in Afghanistan, it managed to retain its influence and take over the country in August 2021. This group has some influential figures. One of them is the founder and original leader of the Taliban, Mullah Mohammad Omar. Omar had gone into hiding when the Taliban was overthrown by America after September 9, 2001 (9/11), and died in 2013. Currently, at least five key figures have played a significant role in maintaining the Taliban in recent years. New Taliban leader Mullah Haibatullah Akhundzada and others are now running Afghanistan, among others:

\section{Haibatullah Akhunzada}

He is known as the "Leader of the Faithful," the leader of those who believes. He holds the final say on the Taliban's political, religious, and military stance. However, during the lead, he tends to cover himself so that no one knows for sure where he is. Maulawi Haibatullah Akhunzada has just been appointed Amir of the Islamic Emirate of Afghanistan. He is a hafiz of the Qur'an, an expert in commentary, Hadith, and the Hanafi school of thought. Maybe he is the only head of state in the world who has such mastery of sharia knowledge.

Yet to be an expert in the science of interpretation. One must master the knowledge of nahwu, shorof, balaghoh, qiro'atsab'ah, fiqh, ushulfiqh, asbabunnuzul, hadith, nasikh wal mansukh. He, who is in his $55 \mathrm{~s}$, is known as an educated figure and is respected by members of the Taliban. According to one of the founders of the

12 BBC reports, Taliban kuasai Afghanistan, dari mana sumber pemasukannya dan seberapa kaya kelompok ini? https://www.bbc.com/indonesia/dunia-58394441. 
Taliban, Muhammad Akbar Agha told CNN, Akhundzada is from Panjwai, a district south of Kandahar province.

Commitment to developing Afghanistan by inviting foreign investors. But only funds come in, while the workers in hotels, malls, and other infrastructure are purely Taliban people." Suppose I do not prosper the people themselves. How will I be held accountable in the hereafter?" Taliban leaders are trying to reshape themselves in a more moderate form: promising amnesty to their enemies, vowing to build an inclusive government with various ethnic groups, keeping terrorist groups off Afghan soil, and allowing women to work within the confines of Sharia law. These are all conditions for the US and its allies to recognize the group as the new legitimate ruler of Afghanistan.

Akhunzada is famous as the "Leader of the Faithful" and is a scholar of Islamic law. He is the supreme leader of the Taliban who wields ultimate authority over political, religious, and military affairs. Akhunzada took over when his predecessor, Akhtar Mansour, was killed in a US drone strike near the Afghanistan-Pakistan border in 2016. For 15 years until his sudden disappearance in May 2016, Akhunzada taught and preached at a mosque in Kuchlak, southwest Pakistan. Akhunzada is around 60 years old, and his whereabouts are unknown.

\section{Mullah Mohammad Yaqoob}

The son of Mullah Mohammad Omar is in charge of the Taliban's military operations. According to news circulating, he was already in Afghanistan. The son of Taliban founder Mullah Omar, Mohammad Yaqoob, was appointed Afghanistan's defense minister. Yaqoob is in a cabinet led by Prime Minister Mohammad Hasan Akhund, who was once an aide to Mullah Omar.

Mohammad Yaqoob is the eldest son of the founder of the Taliban, who died in 2013. Yaqoob graduated from an Islamic religious school in Karachi, Pakistan. Yaqoob is estimated to be around 30 years old.

\section{Sirajuddin Haqqani}

Haqqani manages the Haqqani Network, responsible for the Taliban's financial and defense assets around the PakistanAfghanistan border. By various experts, Haqqani is also believed 
to be the figure who popularized the suicide bombing strategy in Afghanistan.

\section{Mullah Abdul Ghani Baradar}

Mullah Abdul Ghani Baradar is the founder of the Taliban along with Mullah Mohammad Omar. Now, he heads the political office of the Taliban. His position makes him involved in peace negotiations that are unclear in Doha, Qatar.

\section{Abdul Hakim Haqqani}

Abdul Hakim Haqqani is the head of the Taliban negotiating team. He helped Mullah Abdul Ghani Baradar secure a deal that would benefit the Taliban. In addition, he is also a former "judge" of the Taliban and heads a council of clerics.

The Taliban existed during the 1980s in the form of a Taliban guerrilla front, mainly linked to the mujahideen cleric party, Harakat-iEnqelab-Islami (Islamic Revolutionary Movement). The party was demobilized in 1992 and hardly took part in the civil war. The Taliban emerged as an autonomous movement in 1994 but did not adopt guerrilla tactics. They instead fought as a semi-regular force, gathering for conventional combat. Arguably, their military organization is more suited to the available resources (human and financial) than their rivals. Once they captured Kabul in 1996, the Taliban developed something more like a regular army, with some artillery and armor and a small air force, and even combined some popular militia forces.

Haibatullah Akhundzada is still the epicenter of the Taliban movement since his predecessor, Mullah Mansour Akhtar, was killed in a US airstrike in 2016. After being appointed in 2016, Akhundzada received a pledge of allegiance from Al-Qaeda leader Ayman alZawahiri who dubbed him "Amir al-Mu'minin." The admission by the al-Qaeda kingpin is believed to have placed him in an elite position within the jihadist movement and among longtime allies of the Taliban. The mullah has succeeded in reuniting the militant movement disintegrated by the US and Afghan military attacks.

In contrast, Baradar is the most recognized political leader and Taliban figure at home and abroad. Baradar was born in Uruzgan Province and raised in Kandahar, the beginning of the Taliban 
movement. Like other Afghans, his childhood was marred by the bloodshed during the invasion of the Soviet Union in the 1970s, which contributed to his taking up arms.

When the whole country plunged into a war between warlords after the departure of the Soviet Union, he helped his brother-inlaw, Mohammad Omar, open a boarding school that campaigned for the establishment of an Islamic caliphate. The Taliban's power grew until it caught the attention of Pakistan's secret services, which helped Omar to take power in 1996.

In the early period of this golden age, Baradar was regarded as an accomplished strategist and is celebrated as the architect of the Taliban's triumph. However, following the 2001 US invasion, Baradar reportedly approached President Hamid Karzai to offer a deal for the Taliban's recognition of Washington's government.

Baradar was finally arrested in Pakistan in 2010 and released at US President Donald Trump's urging in 2018. The US military believed that Baradar, who tends to have moderate views, could lead the Taliban negotiating team. Since then, Baradar lived in Doha, Qatar, until the conquest of Kabul on August 15, 2021. Despite his status as the leader of the Ummah, Baradar will share power with Haibatullah Akhundzada, who is the official leader of the Taliban. The mullah has been known as a spiritual figure rather than a war commander.

The Taliban's success in taking power in Afghanistan was quickly welcomed by some political and Islamist groups in Southeast Asia. However, security experts warn that the group's rise to power will lift the spirits of other militants. The Afghan government fell 15-17 August 2021 after President Ashraf Ghani fled and the Taliban insurgents took control of Kabul. Taliban insurgents managed to seize control of the nation's capital without any significant opposition after the United States withdrew its military forces, part of the international coalition supporting its government.

As we know, although it still looks chaotic in Afghanistan, the whole thing is a scenario that is neatly arranged and centered on the figure of Mullah Baradar in the following chronology:

1. In 2013, the Taliban allowed Qatar to open a diplomatic office with the approval of America and Afghanistan. Its goal was to facilitate peace in Afghanistan. All countries who want to communicate 
with the Taliban for Afghanistan peace could approach Qatar. Indonesia also met there.

2. On October 25, 2018, Pakistan released Taliban founder Mullah Abdul Ghani Baradar from custody at the request of the United States. In 2019, the US and the Taliban discussed in Qatar.

3. On February 29, 2020, there was the Doha Agreement in Qatar between America and the Taliban. Mullah Baradar represented the Taliban.

4. On July 8, 2021, the Taliban negotiated with Russia and promised not to threaten Russia and its allies. Mullah Baradar led the Taliban delegation.

5. On July 28, 2021, the Taliban negotiated with China and promised not to threaten China. Who is the leader of the Taliban delegation? Mullah Baradar again.

All of them were led by Mullah Baradar. So if today Mullah Baradar returns to Afghanistan, we should understand and not feel nervous or surprised. Maybe Mullah Baradar by the Taliban was prepared as the leader of Afghanistan after Ashraf Ghani and approved by the US/West and Russia.

\section{THE RESPONSE OF INDONESIAN ISLAMISTS TO THE FUTUH OF THE TALIBAN}

As we know, since the fut uh in Afghanistan, Indonesia has become one of the countries that have been in the spotlight by many practitioners on the issue of terrorism. There is a possibility that with its futuh, the Taliban will be able to attract many conservative Indonesian Muslim groups to 'hijrah' to the Mullah country.

On the other hand, Indonesia once had historical attachments to Afghani stan, especially during the invasion of the Red Bear (Soviet Un ion) troops into Afghanistan in the early 80s. At that time, hundreds of Indonesian citizens decided to go to Afghanistan for jihad or participate in tadrib asykari military training with mujahideen groups from Arab countries. At that time, activists from the Islamic State of Indonesia (NII) and Jama'ah Islamiyah (JI) were the two Indonesian jihad organizations that played an important role in Afghanistan. 
Similar conditions also occur in the ISIS group in Syria. When this group first announced the establishment of the Khilafah Islamiyah in mid-2014 by appointing Abu Bakr al-Baghdady as Amirul Mukminin, the response from the Indonesian Brotherhood was quite massive. Various events were held, including peaceful demonstrations, seminars, studies, taklim, mass betrayals, and mass mobilization to emigrate to Syria. Although the ISIS state in Syria has been destroyed, fragments of this group are still found in Indonesia by calling themselves the JAD and JI groups. Therefore, the researchers eagerly to find out whether it has the same influence and lure jihadist groups in Indonesia to 'migrate' to Afghanistan as happened in Syria or not. Four reasons are essential to dig it up. ${ }^{13}$

First, there are differences of opinion in creed, especially takfiri or disbelief in groups considered contradictory. We tried to conform to some ex-terrorism convicts (napiter) who had also been part of the ISIS group. He is Abu Zahra, where currently he is still in contact with the JAD network, especially in the Sulawesi region. Through online communication, he does not deny the existence of these differences."Because the Taliban have different beliefs, especially about their takfiri." Abu Zahra explained when contacted by the author, Saturday (7/8/2021).

Second, the Taliban do not support Daula (ISIS). Even if there is support for ISIS, it is considered not to represent the full authority of the organization.

Third, the proximity of the Taliban elite to Western figures. It is considered an indication of disagreement with the narrative often campaigned by ISIS. Including a delegation from the Taliban to the State Palace in Jakarta in mid-July 2019. Several elite Taliban figures were also present during the visit, such as Mullah Abdul Ghani Baradar (Taliban Deputy Leader) and Zabinhullah Mujaheed (Taliban spokesman). The Taliban delegates met by Vice President Jusuf Kalla in July 2019 explained his desire to build political cooperation relations between Afghanistan and Indonesia in the future. The Taliban's visit to Indonesia to build political cooperation had also reaped the pros and cons, especially among conservative Muslims.

\footnotetext{
${ }^{13}$ Kharis Hadirin, Taliban Menang di Afghanistan dan Pengaruhnya terhadap JAD, https://ruangobrol.id/2021/08/14/fenomena/perdamaian/taliban-menang-diafghanistan-dan-pengaruhnya-terhadap-jad/
} 
Many are in support, but not a few think that the current Taliban has strayed far since the absence of Mullah Muhammed Omar, who is against the West and its influence.

Fourth, the Taliban are considered apostates by ISIS. One of the magazines that are also a propaganda tool for ISIS, the 10th edition of Rumiyah in $1438 \mathrm{H}$ or around May 2017, has released a fatwa about the heresy of the Taliban. This edition also explains that the Taliban is considered to have disobeyed and all its members have apostatized. The Taliban and the fatwa were also given to the al-Qaeda group led by Aiman al-Zawahiri for refusing to take allegiance to the leader of ISIS, Abu Bakr al-Baghdadi.

Meanwhile, thenarrativeonsocialmediaofJamahAnsharutDaulah (JAD) symp athizers also gives much negative attention to the Taliban. One of them is a Facebook account. It can be seen on one of the Facebook social media accounts belonging to a sympathizer of the Jam aah Ansharut Daulah (JAD) group, "Boru Xinai." The difference between DauIah Islam and organizations that act in Islam and Mujahideen, such as al-Qaeda and the Taliban, is basic aqidah, kufr bi thaghut (denial of thaghut). Especially thoghut Ashabiyah Nationalism, nationality and democracy. And also kufr with thaghut law. That is to disobey artificial laws and state division laws.

There is no tolerance in it, unlike what al-Qaeda and the Taliban did in Afghanistan, which only aims to establish an "Islamic" area of particular nationalism for Afghanistan and open an embassy in Qatar, which means recognizing the legitimacy of the thaghut state of Qatar." he wrote on his Facebook page.

Regarding the response of Indonesian Islamists to the futuh of the Taliban, this paper attempts to answer why Islamists in Indonesia show a hidden euphoric response to the fall of Kabul. The fall of US-backed and multinational superpower President Ashraf Ghani in Kabul to the Taliban on August 15, 2021, is a significant event of the century, marking a new era of Sunni Islamic power outside the Shia and Wahabi denominations. This event is called the second Afghan futuh (fall of Afghanistan). The first Afghan futuh occurred when the Soviet Union was forced out of power in 1989.

The Afghan futuh incident is also referred to as the Taliban futuh by some Islamists in Indonesia. Although semantically the meaning is not precise, the Muslim public understands it as a victory for the 
Taliban. They have twice been able to expel two of the world's superpowers: the Soviet Union and the US, supported by the militaries of other multinational countries. Immediately, the Muslim public in Indonesia greeted him with astonishment and joy, although not as enthusiastically as the first Afghan futuh (1989). Even Habib Rizieq Shihab and other Islamist leaders did not convey their condolences to the futuh of the Taliban.

However, there is an impression that this joy is deliberately hidden and does not appear as euphoria, not because of the Covid-19 pandemic, but because the Islamists are not feeling well under the current regime, which is considered not friendly enough to them.

The Islamists in Indonesia feel they are under pressure, not accommodated in the power system, and their relationship with the state is problematic. They are not lucky. Some of the public still sneer at each other and are suspicious not only because of the effects of the election a few years ago but indeed because of different cultural references. One is very secular, while the other is very rigid and fanatical. Socio-political settings like this still illustrate that Indonesia's social, cultural, and political integration has not been completed.

Indonesian Islamists regret the severed political ties between the Republic of Indonesia and the Islamic Emirate of Afghanistan. Whereas previously, the Taliban had established good relations with the New Order under Suharto's leadership in 1995 and the visit of the Taliban delegation to Indonesia on July 28, 2019, which Vice President Jusuf Kalla welcomed.

Many hopes that Indonesia has placed on the shoulders of the Taliban to be inclusive, implement Islam that is wasathiyah (moderate) and provide space for women to work and go to school. At that time, Indonesia had realized that the Taliban would soon take control of Afghanistan because the US was planning to leave the Silk $\mathrm{R}$ oad region. The response of Islamists in Indonesia, especially Jamaah Islamiyah, which has had close communication and relations with the Taliban, has been relatively positive. Jamaah Islamiyah (JI) has severed ties with Al Qaeda and was sidelined by ISIS due to various interests and ideologies. The difference is that JI rejects the Takfiri ideology, understands disbelieve in other people, understands that it is easy, and has the heart to kill those outside the 
group. Moreover, ISIS adheres to the Takfiri ideology and justifies the killing of Muslims. It is fierce to slaughter fellow Muslims who are considered outside their group.

Indonesian Islamists also feel sad if the Taliban is considered an agent of terrorism. The general public in Indonesia can still distinguis $h$ between al Qaeda as a sponsor of terrorism and the Taliban as a freedom fighter. In 2001, after the September 11 WTC attacks, the US pressured the Taliban leader, Mullah Omar, to hand over Osama bin Laden. Mullah Omar plans to try Osama bin Laden in a sovereign Afghan court.

Before the plan was implemented, the US, under the leadership of George Bush, invaded Afghanistan and took 17 years to find its hiding location in Abbottabad, Pakistan. Suppose the US could respect the legal jurisdiction of Afghanistan, then in just a few days. In that case, Osama bin Laden could be extradited to the US.

Indonesian Islamists and some radical Islamists in Southeast Asia, such as sympathizers supporting ISIS (Islamic State of Iraq and Syria), actually show the opposite attitude. ISIS, better known as ISIS (Islamic State of Iraq and Syria), considered the Taliban a sworn enemy and branded them as infidels even though they have the same belief.

ISIS has repeatedly fought the Taliban in Khurasan, Paktiya, Helman, and Nangarhar. The Taliban is the most significant player in Afghanistan. Al-Qaeda is a transnational jihadist group seeking to rebuild its network. Likewise, ISIS's struggle will not be easy because they are sworn enemies of al-Qaeda and the Taliban (Colin Clarke, 2020).

The Taliban have proved to be down-to-earth despite gaining power in Kabul. The international community, including Indonesia, is still reluctant to de jure acknowledge this unique Islamic power. It is said to be unique because Afghanistan under the Taliban has changed. A country with a nomocracy system will become a rival to the Western-style democratic system, the royal system a la Saudi Arabia, Malaysia, and Brunei, and the theo-democracy system of Iran.

The nomocracy system was built from the ground up without political parties in the hope of Islamists in Indonesia who feel tired and fed up with oligarchic democracy. The Taliban militant group 
previously declared an amnesty across Afghanistan and urged women to join its government. Mujahid said he wants to assure the international community, including the United States. No one will be harmed. He doesn't want to have any internal or external enemies. Taliban spokesman Zabihullah Mujahid (left) signaled as he arrived to hold the first press conference in Kabul on August 17, 2021, after the stunning takeover of Afghanistan by the Taliban.

The Taliban is trying to give a moderate image of its government which was seen as cruel in the late 1990s. With this, Mujahid said that his group had grown. The Taliban, Mujahid said, will not take the same actions as they did in the past. The group is also committed to protecting the rights of the press and women and children. Mujahid told reporters gathered. The problem is that in this era of the Taliban, billions of dollars of Afghan assets and funds abroad have been frozen by the US/West. In contrast, the Taliban is facing a severe economic and humanitarian crisis. So it makes sense and is very reasonable if the Taliban ask the United States (US), Europe, and other countries to disburse these funds and officially recognize their government in Afghanistan so as not to cause problems for Kabul and the international community.

The Taliban also do not plan to carry out retaliatory attacks against those who served in the previous government, foreign forces, or the Afghan military. Meanwhile, responding to the Taliban's promise to respect women, activist Malala Yousafzai said she was pessimistic. The youngest Nobel Peace Prize winner admits he is worried about the fate of women in Afghanistan. The meeting was held between the Taliban and representatives from the United States in February 2020.

The United States has sought peace as long as the Taliban is committed to turning Afghanistan into a terrorist state. "What happened today departed from the decision to negotiate between the Taliban and US representatives at the end of February 2020. That is the basis. The US has asked that if there is a change in relations in the future, the Taliban is committed not to make the land of Afghanistan as a foundation or earth for terror groups.

Since taking over the country, the Taliban said women would be free to work in the first press conference. Taliban spokesman Zabihullah Mujahid said on Tuesday (17/8/2021) that women's rights 
would be protected. "We will allow women to work and study. We have a framework, of course. Women will be very active in society, but within an Islamic framework," Mujahid said. He also said the Taliban wanted peaceful relations with other countries.

\section{CONCLUSION}

As we know, billions of dollars of Afghan assets and funds abroad have been frozen by the US/West, even as the country faces a severe economic and humanitarian crisis. Therefore, the Taliban asked the United States (US), Europe, and other countries to disburse these funds and officially recognize their government in Afghanistan so as not to cause problems for Kabul and the international community.

Indonesian and Southeast Asian Islamists are generally of the view that with the initial intention and decades of tarbiyah by upholding Islam and Muslims in Afghanistan, with solid knowledge and belief control, so that it can be used as a guarantee that the Taliban in the fut ure will walk in the same direction as what was proclaimed by the founding fathers of Afghan, namely rebuilding a sovereign Afghanistan, with dignity, respecting and protecting human rights, respecting women and children and establishing peace in the world.

The government of the Taliban in Kabul was aware that his victory was greeted with hope and anxiety by the West because it was feared that it would trigger a clash of Islamic and Western civilizations in the Central Asian region and at the global level. But this should not be necessary because the Taliban government wants to cooperate honorably, respectfully, and peacefully with the West and all countries in the world as soon as possible. The Taliban government needs international and Western economic assistance to strengthen its existence and struggle to form a peaceful Islamic government, uphold human rights and protect women and children.

\section{REFERENCES}

Antonio Giustozzi, The Islamic State in Khorasan: Afghanistan, Pakistan and the New Central Asian Jihad (HURST publisher 2018). 
Antonio Giustozzi, The Taliban at War 2001 - 2018, Oxford University Press, 2019.

Antonio Giustozzi . Koran, Kalashnikov, and Laptop: The NeoTaliban Insurgency in Afghanistan 2002-2007. New York: Columbia University Press, 2007.

Andrew R. Smith, Belling the cat: The neo-Taliban insurgency in Afghanistan, Master thesis, University of New Hampshire, Durham,2011

Anthony Davis. "How the Taliban Became a Military Force." In Fundamentalism Reborn? edited by William Maley. New York: NYU Press, 1998

Al Chaidar, Respon Kaum Islamis Indonesia Terhadap Futuh Taliban - https://modusaceh.co/news/respon-kaum-islamisindonesia-terhadap-futuh-taliban/index.html.

Al Jazeera (20/8/2021), تفاصيل السقوط السريع لحكومة أفغانستان.. كيف انتصرت طالبان وفشلت إستراتيجية واشنطن؟ https://www.aljazeera.net/midan/reality/po litics/2021/8/20/\%D8\%B9\%D9\%84\%D9\%89-

After Taliban Takeover, Can Afghanistan's Economy Survive?

https://www.usip.org/publications/2021/09/after-taliban-takeovercan-afghanistans-economy-survive. See, https://www.bbc. com/indonesia/dunia-58394441

BBC reports, Taliban kuasai Afghanistan, dari mana sumber pemasukannya dan seberapa kaya kelompok ini? https://www. bbc.com/indonesia/dunia-58394441

David B. Edwards, Before Taliban: Genealogies of the Afghan Jihad, (California: University of California Press, 2002).

Herdi Sahrasad and Al Chaidar, Indonesian Terrorist, ISIS, and Globalization of Terror: A Perspective http://journal.uinjkt. ac.id/index.php/ahkam/article/view/7494/5250, Vol 18, No 1 (2018).

Herdi Sahrasad and Al Chaidar, ISIS, Indonesian Muslims and the Global Ultra Revivalists for Global Terrorism: A Perspective, 
working paper, Freedom Foundation, and PSIK, Paramadina University, Jakarta, July 2016.

Kharis Hadirin , Taliban Menang di Afghanistan dan Pengaruhnyaterhadap JAD, https://ruangobrol.id/2021/08/14/ fenomena/perdamaian/taliban-menang-di-afghanistan-danpengaruhnya-terhadap-jad/

Musthafa Abd. Rahman, Afghanistan di Tengah Arus Perubahan: Laporan dari Lapangan, (Jakarta: Kom-pas, 2002)

Samuel Huntington, The Clash of Civilizationand the Remaking of World Order, Simon and Schuster, 1996.

Salim Basyarahil, Perang Afghanistan, (Jakarta: Gema Insani Press, 1986)

التطورات في أفغانستان: كاذا انهارت القوات الحكومية الأفغانية أمام تقدم طالبان؟ Www.bbc.com https://www.bbc.com/arabic/inthepress-58226702

نيويورك تايمز: أمريكا تفاوض طالبان لتجنب استهداف سفارتها لدى Www.masrawy.com أفغانستان

https://www.masrawy.com/news/news_publicaffairs/details/2021/ 8/13/2071924/\%D9\%86\%D9

Fakta Taliban, https://www.republika.co.id/berita/qxwuqw320/12fakta-tentang-taliban-yang-kembali-kuasai-afghanistan-part 1.

Tentang Taliban, https://nu.or.id/opini/mengenal-taliban-ideologipolitik-dan-watak-keberislamannya-izRJa

Thomas Barfield. Afghanistan: A Cultural and Political History. Princeton, NJ: Princeton University Press, 2010.

Interview with Nasir Abbas and Noorhuda Ismail and a diplomat Afghanistan in Jakarta in early September 2021 